\title{
Considerações acerca do Prefácio de Ducrot na obra O Intervalo Semântico, de Vogt
}

\section{Considerations about the Preface by Ducrot, in The Semantic Interval, by Vogt}

Samuel Henrique Machado

Cristiane Dall' Cortivo Lebler ${ }^{2}$

Universidade de Santa Cruz do Sul, Programa de Pós-Graduação em Letras. Santa Cruz do Sul, RS, Brasil.

Mestrando em Letras - área de concentração Leitura: estudos linguisticos, literários e midiáticos (1)

E-mail: samumachado@yahoo-2514-5877

Doutora em Letras - área de concentração Linquistica pela Pontifícia Universidade Católica do Rio Grande do Sul, com dissertação e tese na linha de pesquisa Texto, Enunciaçăa, Discurso: teoria prática. Alua como professora do Departamento de da Universidade de Santa Cruz do Sul. iD hntps:/lorcid org/0000-0003-3389-1850 E-mail: cristianedc@unisc.br
RESUMO: O objetivo central deste estudo é analisar as conjecturas e teorizações de Oswald Ducrot em seu Prefácio à obra $O$ Intervalo Semântico, de Carlos Vogt. 0 propósito inicial é reconstituir as inferências de Ducrot, que passam pelo diálogo Sofista, de Platão, as quais o autor empregasobretudo no que ele revela acerca do gênero outro - na elucidação do intervalo semântico de que fala Vogt. Por fim, propõe-se levantar uma questão (e, ao mesmo tempo, a pertinência dessa questão) sobre a natureza do enunciado, de seu valor argumentativo, segundo Ducrot, sobretudo em relação à suposta semelhança que guarda com a natureza discursiva própria dos sofistas.

Palavras-chave: Ser/não-ser; Enunciado; Argumentação; Intervalo semântico.

ABSTRACT: The main aim of this study is to analyze the Oswald Ducrot's conjectures and theorizations in his Preface to the book The Semantic Interval, by Carlos Vogt. The initial purpose is to reconstruct Ducrot's inferences, which pass through the Sophist dialogue, of Plato, which the author uses - especially in what he reveals about gender other - in the elucidation of the semantic interval of which Vogt speaks. Finally, it is proposed to raise a question (and at the same time, the pertinence of this question) about the nature of the statement, its argumentative value, according to Ducrot, especially in relation to the supposed similarity that it maintains with the own discursive nature of the sophists.

Keywords: Being/non-being; Statement; Argumentation; Semantic interval. 


\section{Introdução}

Yis

s um paradoxo: se todo ser é diferente de si mesmo, então não pode participar do mesmo ser. Contudo, o que substancialmente é diferente de si mesmo só pode ser reconhecido enquanto tal quando em comparação com o mesmo absoluto. Ou seja, qualquer não-ser (enquanto diferença absoluta) é também um ser, na medida em que é comparado a um ser permanente.

Em outras palavras, quando sua distinção (de não-permanência) é pensada, é ela, justamente, a sua provedora de identidade possível, qual seja, de que o ser do não-ser é sempre um perpétuo devir, em contradição ao que é permanente - tal como com a definição "homem, animal racional", que só pode ser entendida enquanto imutável se for comparada à sua (im) possibilidade oposta, "homem, animal não-racional".

Isso implica que o Ser, enquanto identidade absoluta, perfeita e, portanto, imutável, existe na ordem do inteligível, ou seja, da natureza do suprassensível ou do "plano das ideias" platônico. Esse plano apresenta a impossibilidade de que o Ser possa ser apreendido substancialmente pelos sentidos. Sua apreensão, adverte Platão, dá-se tão somente pela razão lúcida que pressupõe a episteme, "um tipo de saber que, diferentemente da opinião (doxa), é certo, estável e fundamentado, ou seja, dotado de garantias incontroversas de validade" (ABBAGNANO, 2007, p. 391).

Ora, o que essa elucubração em torno do que se pode dizer sobre o Ser tem a ver com "argumentação", ou com "enunciado"? O linguista francês Oswald Ducrot responde a essa pergunta no Prefácio que escreveu à obra O Intervalo Semântico do poeta e linguista brasileiro Carlos Vogt.

O presente trabalho é instigado pela escassez de produção sobre o Prefácio - escassez esta que surpreende bastante, dada a sua relevância teórica. Sendo assim, o objetivo, neste estudo, é produzir uma análise das conjecturas de Ducrot (ainda que com o risco de diminuí-las) sobre o intervalo semântico de que fala Vogt, pois são conjecturas capitais para entender a própria argumentação na língua.

O projeto deteve-se, primeiramente, na elucidação do diálogo Sofista, de Platão, pois compreendeu-se que, por ter Ducrot se utilizado dele para erigir suas inferências, o Sofista deveria ser também aqui ilustrado em seus fundamentos, principalmente no tocante aos gêneros movimento, repouso, ser, mesmo e outro, constitutivos da questão metafísica sobre a natureza do Ser e do sentido da argumentação, segundo Ducrot.

Em seguida, sucedeu-se o exame do Prefácio de Ducrot, sendo que alguns exemplos apresentados pelo autor foram aqui alocados, com outros termos e predicativos e com outra ordem, objetivando ampliar ainda mais o horizonte de sentido do Prefácio.

Por fim, propõe-se um questionamento sobre a natureza da argumentação, de acordo com a definição de Ducrot, tomando por objeto o modus operandi do uso discursivo dos sofistas, no sentido de que este guarda (possivelmente) certa semelhança com aquele.

\section{0 diálogo Sofista: uma primeira noção do sofista}

No diálogo Sofista ${ }^{1}$, Platão apresenta questões-chave de sua dialética e de sua teoria das ideias. O título, de certa forma, pode ser considerado enganoso ao leitor, dado que a maior parte da discussão dialógica, no nível mais profundo, não gira tanto em torno do que se pode dizer acerca da natureza do sofista, mas, sobretudo, gira em torno da questão chave filosófica mais difícil, a saber, o que se pode dizer sobre o "ser" (sua ordem e natureza)?

1 "Sofista", segundo a tradução de Jorge Paleikat e João Cruz Costa, na Coleção Os Pensadores da Abril Cultural (1979), a qual é utilizada nesse trabalho. Em outras traduções, como a de Carlos Alberto Nunes, lê-se "O Sofista". 
No entanto, logo no princípio do diálogo, vê-se que Sócrates apresenta um problema ao Estrangeiro de Eléia (personagem anônima), o de distinguir os gêneros "sofista", "político" e "filósofo", o que, portanto, justifica o título para o diálogo. Quanto à tarefa de Sócrates para o Estrangeiro, após este tê-la aceitado sem relutâncias, Sócrates o questiona: "Mas dize-nos antes se, de costume, preferes desenvolver toda a tese, que queres demonstrar, numa longa exposição ou empregar o método interrogativo?" (1979, 217c). Com tal questionamento, Sócrates já se antecipa em testar se não é ele próprio, o Estrangeiro, um sofista ou um político, pois o método de "longas exposições" discursivas é, justamente, o método empregado por estes - o que faria Sócrates mudar totalmente sua postura em relação à confiabilidade discursiva do Estrangeiro.

Entrementes, responde o Estrangeiro:

Com um parceiro assim agradável e dócil, Sócrates, o método mais fácil é esse mesmo: com um interlocutor. Do contrário, valeria mais a pena argumentar apenas para si mesmo. (...) Na realidade, a questão em que tocamos não é assim tão simples como parece, na maneira por que a propões; ao contrário, ela exige uma longa conversação (1979, 217d).

Assim, ao aceitar o método interrogativo, que pressupõe a presença necessária de um interlocutor e cujo mecanismo propulsor é o jogo de perguntas e respostas que pretende sempre conduzir o interlocutor à reflexão mais lúcida e, por conseguinte, ao "parto das ideias" (maiêutica) claras e distintas, o Estrangeiro escolhe trilhar exatamente o mesmo caminho socrático-platônico e, nessa perspectiva, põe-se à altura de um filósofo ${ }^{2}$, cuja humildade está a serviço do saber.

\footnotetext{
2 Cabe dizer que, para Platão (que, por sua vez, endossa seu mestre Sócrates), a verdadeira filosofia inicia pelo diálogo epistêmico (dialético), por ser o mais condizente com a austeridade intelectual e moral, ou seja, despossuído das vaidades pretenciosas das "longas exposições" de discursos persuasivos e, para ele, antipedagógicos.
}

A partir de então, o Estrangeiro e seu interlocutor, o jovem matemático Teeteto $^{3}$, concordam em definir primeiramente o sofista, e concordam em fazê-lo partindo da investigação de "um assunto simples qualquer, procurando nele encontrar um modelo para o nosso tema grandioso" (1979, 218d). Nesse viés, de construção da identidade do sofista, o Estrangeiro acaba por erigir também a noção precisa do que vem a ser um filósofo.

De princípio, o Estrangeiro problematiza a natureza da arte em duas vias:

1. A via de "todo trabalho relacionado ao que é composto e fabricado" (1979, 219a), ou seja, como modo de produção das coisas que parte do "não-ser" (daquilo que ainda não se tornou o produto final), para a produção do "ser" (o produto final): "ESTRANGEIRO - Das coisas que do não-ser anterior foram posteriormente tornadas ser, não se dirá que foram produzidas, pois que produzir é tornar ser, e ser tornada é ser produzida? TEETETO - É certo" (1979, 219b).

2. A via do "sempre preexistente, ou do já produzido que ou bem é apoderado pela palavra ou pela ação, ou bem é defendido contra quem pretenda dele apossar-se" $(1979,219 b)$. Trata-se, pois, da arte da coisa adquirida.

Assim, postas as vias da arte (de produção e de aquisição), o Estrangeiro pergunta a Teeteto em qual delas se enquadra o pescador por anzol. Este responde que se enquadra na arte da aquisição. Contudo, o Estrangeiro diferencia também duas vias dessa arte por aquisição: a que se dá pelo consentimento das partes e a que se dá pela captura. Essa última, por sua vez, também é dividida em duas: a captura que ocorre às claras (implicando a luta) e a captura por armadilha (implicando a caça). No jogo dialógico do 3 Teeteto é também o título de outro diálogo de Platão, em que se discute a natureza do conhecimento
e em que aparece a distinção entre relativismo e verdade. As personagens que compõem este diálogo são Sócrates, o próprio Teeteto e Teodoro de Cirene. 
Estrangeiro, as vias dicotômicas não cessam de se inscrever - e será assim até o fim do diálogo: o próprio método de captura pela caça pressupõe também dois tipos de objetos a serem caçados, a saber, os inanimados e os animados (seres vivos aquáticos, terrestres e os que voam).

Após uma série de conjecturas e inferências lógicas dedutivas em torno da arte do pescador por anzol, o Estrangeiro leva Teeteto a concluir que esta apresenta um modus operandi de regras sucessivas, e que pode ser resumida como sendo a arte especializada em (a) pôr a vítima em vulnerabilidade para, então, (b) fisgá-la. Ora, o Estrangeiro (como já era de se esperar de um filósofo ao estilo de Sócrates e Platão) começa, assim, a definir a natureza do sofista como a de um caçador ardiloso, cujas vítimas são seus ouvintes.

Para o Estrangeiro, entretanto, a caça do sofista é mais pretenciosa, porque interesseira: por meio de galanteios e lisonjas, o sofista convence sua caça (comumente os jovens muito ricos) a aprender o seu método de persuasão e a pagar caro por isso.

ESTRANGEIRO - Recordando, pois, o nosso raciocínio, parece-me, Teeteto, que na arte da captura, na caça aos seres vivos, às presas da terra firme, aos animais domésticos, ao homem como indivíduo, na caça interesseira em que se recebe dinheiro a pretexto de ensinar, na caça que persegue os jovens ricos e de alta sociedade, encontramos o que devemos chamar, como conclusão do nosso próprio raciocínio, de sofística.

TEETETO - Certamente (PLATÃO, 1979, 223b).

Quanto ao método sofístico, este é definido, pelo Estrangeiro, como sendo a arte de persuadir por meio do uso da erística (técnica de debates contestatórios, nos quais cada debatedor tem sempre o dever de vencer o argumento de seu oponente, ainda que esse argumento não revele - ou nem mesmo se aproxime de - verdade alguma). Trata-se, pois, de um método de argumentação pelo uso de contestações e artimanhas, cujo único objetivo é vencer o combate.
ESTRANGEIRO - Assim, tão simplesmente como parece, o gênero que recebe dinheiro, na arte da erística, da contradição, da contestação, do combate, da luta, da aquisição, é o que, segundo a presente definição, chamamos de sofista.

TEETETO - Certamente (PLATÃO, 1979, 226a).

O Estrangeiro elenca ainda a ignorância como característica simbiótica a esse método. Isso porque tal método de argumentação erística impõe a prática do argumentar pela exclusiva necessidade de vencer o debate, o que, por sua vez, faz protagonizar um jogo de articulações discursivas contraditórias que não necessariamente - repita-se - tem de estar compromissado com a verdade. Basta, pois, que a verdade seja aparente e apresentada de modo convincente. O problema é que tal prática leva os debatedores/contraditores a presumir que, por dominarem a erística, dominam, igualmente, os conteúdos de seus argumentos.

Assim, acabam por ser enganados pela própria prática argumentativa, que prediz serem, eles, os debatedores, dominadores da comunicação sobre quaisquer questões, sejam questões gerais "do devir ou do ser (...) e, ainda, a propósito das leis e de todas as coisas políticas” (1979, 252c-d).

Entende, pois, o Estrangeiro, que tal método pressupõe um poder prestigioso ou que dá a impressão a quem o domina de ser onisciente, mas, em verdade, trata-se de uma armadilha alienante, por um mero utilizar-se de "simulacros que transportam palavras" (1979, 234e) e que tem o poder de tornar o falso em algo real e o real em algo falso. Sobre tal "onisciência", presumida nesse método, o Estrangeiro observa:

Creio, pelo menos, distinguir uma forma especial de ignorância, tão grande e tão rebelde que equivale a todas as demais espécies.

TEETETO - Qual é ela?

ESTRANGEIRO - Nada saber e crer que se sabe; temo que aí esteja a causa de todos os erros aos quais o pensamento de todos nós está sujeito (PLATÃO, 1979, 229c). 
A partir desse paradoxo, em que o falso (discurso) é tomado por real e vice-versa, o Estrangeiro articula uma profunda reflexão em torno da questão do não-ser e do ser, enquanto diferença e identidade absolutas.

\section{0 diálogo Sofista: a questão do ser e do não-ser}

Ora, o próprio Estrangeiro concorda em subscrever seu mestre Parmênides, de que sobre o não-ser nada se pode dizer, pois dizê-lo significa predicá-lo um ser, o que, em si, não condiz com lógica alguma. Todavia, ele pretende transcender a seu mestre - sem que seja tomado por um parricida:

ESTRANGEIRO - (...) para defender-nos, teremos de necessariamente discutir a tese de nosso pai Parmênides e demonstrar, pela força de nossos argumentos que, em certo sentido, o não-ser é; e que, por sua vez, o ser, de certa forma, não é.

TEETETO - Evidentemente, esse é o ponto que deveremos debater em nossa discussão (PLATÃO, 2009, 241c).

Eis uma crítica do Estrangeiro aos pré-socráticos (séculos VII e V a.C.), os iniciadores da filosofia grega, que procuravam, com suas elucubrações, justificar o elemento universal (arché) que originou todas as coisas existentes na natureza (physis). Para ele, os pré-socráticos não procederam "a uma análise cuidadosa" (1979, 242c).

A título de exemplificação e abrangência de compreensão acerca do que o Estrangeiro articula desse ponto em diante sobre o não-ser e o ser, é necessário expor as defesas de dois grandes filósofos pré-socráticos, de pensamentos opostos, quanto ao ser mais primordial; são eles, Heráclito e Parmênides.
O primeiro defendeu que ninguém pode "entrar duas vezes no mesmo rio, pois novas águas correm sobre" (2006, frag. 41) ${ }^{4}$ o indivíduo. Heráclito apresenta, com isso, o princípio universal do devir, ou seja, o devir que prediz que o ser de todas as coisas está em perpétuo movimento (exceto o próprio movimento). Em outras palavras:

Platão expressa a ideia com bastante clareza. "Nada é, tudo se transforma"; "Todas as coisas estão em movimento, como torrentes"; "Tudo passa e nada permanece". (...) Com efeito, Heráclito sustentava que qualquer coisa, por mais estavel que fosse em aparência, era apenas um segmento do fluxo, e que a matéria de que se compunha nunca era a mesma em dois momentos consecutivos (BURNET, 2006, p. 161).

Já o segundo filósofo defendeu que o ser é imutável, uno e indivisível. Sendo assim, "resta-nos falar apenas de um caminho, o é. Há nessa trilha inúmeros sinais de que o que é é incriado e indestrutível, pois é completo,

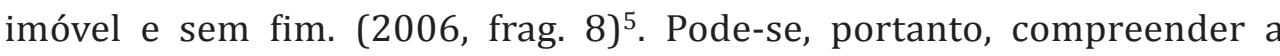
justificação de Parmênides sobre o ser, enquanto a afirmação do que "é", como equivalendo

(...) exatamente a isto: que o Universo é um plenum e que não há nada que se assemelhe ao espaço vazio, quer dentro, quer fora do mundo. Decorre daí que não pode haver algo como o movimento. Em vez de dotar o Um de um impulso de mudança, como fizera Heráclito, e, portanto, torná-lo capaz de explicar o mundo, Parmênides descartou a mudança como uma ilusão. Mostrou de uma vez por todas que, se o Um for levado a sério, é forçoso negar tudo o mais (BURNET, 2006, p. 194-195).

Entretanto, sobre essa mesma tese, em torno de uma suposta unidade do ser, o Estrangeiro problematiza: se Parmênides descreve o ser como

4 Extraído da célebre obra A aurora da filosofia grega, de John Burnet (Rio de Janeiro: PUC-Rio, 2006), onde estão compiladas as melhores versões para cada conjunto de fragmentos dos filósofos présocráticos. 5 Ibidem. 
um Todo, "semelhante a uma esfera bem redonda, em todas as suas partes, do centro, igualmente distante, em todos os sentidos" (apud PLATÃO, 1979, 244e), então "o ser que é assim tem um meio e extremidades; e, desse fato, necessariamente tem partes” (1979, 244e). Ou seja, para o Estrangeiro há um problema lógico na definição do Todo-Uno de Parmênides, a saber, por suas dimensões descritas (com partes), tem de ser divisível.

Dito de outro modo, se o Todo-Uno pode ser divisível, então a totalidade de suas partes corresponde a um Todo-plural (conjunto de unidades). Sendo assim, "a totalidade seria maior que um" $(1979,256 \mathrm{~b})$, pois tal Todo-plural, por ser constituído de várias partes, não é, na totalidade de suas partes, um ser propriamente dito, justamente por ser divisível (composto por vários "seres"). Com efeito, ocorre que esse Todo (enquanto totalidade das partes) já não pode ser reconhecido como Uno. A divisão das partes do Todo implica a impossibilidade de unidade (Uno) do ser desse Todo. Conclui-se, pois, que o ser de Parmênides é um não-ser.

Em seguida, o Estrangeiro trata de problematizar o devir e o ser, tomando o primeiro na ordem do sensível/corpóreo, e o segundo na ordem do suprassensível/incorpóreo. Desse modo, o devir estaria para o simulacro (para as aparências) e o ser para o verdadeiro. Ou seja, nas palavras da personagem Estrangeiro:

E é pelo corpo, por meio da sensação, que estamos em relação com o devir; mas pela alma, por meio do pensamento, é que estamos em comunhão com o ser verdadeiro, o qual dizeis vós, é sempre idêntico a si mesmo e imutável; enquanto que o devir varia a cada instante (PLATÃO, 1979, 248a).

O ser, nesse sentido, é perfeito. Sendo perfeito, não pode mudar, pois tudo que muda o faz ou para melhor (porque ainda não é perfeito) ou para pior (o que implica um absurdo ao próprio conceito de "perfeito"). Outrossim, tal imutabilidade pressupõe a imobilidade. Ou seja, o ser é sempre o mesmo e, com efeito, não pode receber nenhuma ação sobre si.

\section{0 diálogo Sofista, de Platão: a questão dos gêneros}

A partir de tal conjectura é que o Estrangeiro tratará de definir, de modo específico, o repouso e o movimento - na verdade, peças-chave no diálogo. Contudo, ao defini-los, se faz pressentir imediatamente um terceiro gênero, o ser, pois, se para definir algo é preciso desvelar o seu ser, então esse algo é necessariamente um ser. Ambos sendo um ser, eis que se recai sobre um problema: se o repouso é um ser, então este ser é a imobilidade, pois tudo que é repouso permanece imóvel. Por outro lado, se o movimento é também um ser, então este ser é a mobilidade, pois todas as coisas que se movem constantemente jamais repousam. Todavia, como pode o Ser absoluto (o Todo) ser dotado por esse antagonismo? Pois se, logicamente, todos os seres existentes derivam (arché) do Ser absoluto (o Todo), como pode que dois conceitos se excluam, substancialmente?

ESTRANGEIRO - Creio que em nenhuma parte é fácil; pois, se uma coisa não se move, como é possível que não esteja parada? E como deixará de ter movimento aquilo que nunca está quieto? Portanto, o ser revelou-se agora separado dos dois. Isto é possível?

TEETETO - É a coisa mais impossível entre todas (PLATÃO, 1979, 250d).

O próprio Estrangeiro, incitador do problema, admite não ser necessário debruçar-se sobre essa questão, ao menos por ora, devido a dificuldades metafísicas. Convida, então, seu jovem interlocutor para seguirem em frente na discussão acerca dos predicados e da comunidade dos gêneros, acreditando que em momento oportuno possa surgir alguma luz para o problema do antagonismo no Ser. Iniciam predicando o ser "homem". A este são atribuídos 
(...) cores, formas, grandezas, vícios e virtudes; em todos esses atributos, como em inúmeros outros, não afirmamos apenas a existência do homem, mas ainda do bom, e outras qualificações em número ilimitado. 0 mesmo se dá com todos os objetos: afirmamos, igualmente, que cada um deles é um, para logo a seguir considerá-lo múltiplo e designá-lo por uma multiplicidade de nomes (PLATÃO, 1979, 251b).

Mais uma vez, eis que o problema da unidade do ser se coloca, pois ao se predicar um ser se admite sua pluralidade e, com efeito, sua impossibilidade de ser Uno. Esse paradoxo ser=não-ser dá-se de modo contundente e incessante na definição do ser. No entanto, voltando ao sofista, o Estrangeiro lhe predicará justamente a insistência infeliz de manter-se, em seu discurso, no não-ser (fundador do discurso falso), apregoando um suposto ser (fundador do simulacro do real).

Em verdade, o Estrangeiro, com isso, já está apresentando indícios claros de que o ser e o não-ser participam do discurso do filósofo, no sentido de que fundamentam o jogo dialético do conhecimento, considerado por Sócrates e por Platão o instrumento pedagógico por excelência para a possibilidade de um saber sólido.

Retomando a questão dos gêneros, uma vez postos em discussão (o repouso, o movimento e o próprio ser), presumindo dedutivamente que os dois primeiros não são associáveis um ao outro, mas que associam-se, ambos, ao terceiro, o Estrangeiro, mais uma vez, enreda seu jovem interlocutor em um problema ainda maior. Senão vejamos:

¿ Argumento $1 \rightarrow 0$ repouso e o movimento, em função da impossibilidade de se associarem, são, um e em relação ao outro, um outro. Ou seja, o repouso não pode ser o mesmo que o movimento, pois não são associáveis um ao outro. Com efeito, diante de seu oposto (o movimento), o repouso nada mais é que um outro - e vice-versa.

\& Argumento $2 \rightarrow 0$ repouso, impossibilitado de ser o mesmo que o movimento, por não se associarem um ao outro, revela-se, com efeito, como sendo o mesmo a si próprio. 0 mesmo se diz do movimento.

Em busca de uma solução possível para a questão do Ser, o Estrangeiro e seu interlocutor concordam em encontrar um denominador comum. Vejamos: o movimento é o primeiro gênero e "ele é absolutamente outro que não o repouso. (...) Entretanto ele 'é' pelo fato de participar do ser" (1979, $255 \mathrm{e}-256$ a, grifo nosso). É dito, ainda, que "o movimento é outro que não o mesmo. (...) Então ele não é o mesmo” (1979, 256 a, grifo nosso), já que, por estar sempre em permanente mobilidade, ele nunca permanece o mesmo ou porque, em relação a outrem, ele será outro que não o mesmo (que o repouso). Todavia, ele só é o mesmo em relação a si próprio.

Tem-se, em outras palavras, que

o movimento é o mesmo e não o mesmo: é necessário convir nesse ponto sem nos afligirmos, pois, quando dizemos o mesmo e não o mesmo não nos referimos às mesmas relações. Quando afirmamos que ele é o mesmo é porque, em si mesmo, ele participa do mesmo, e quando dizemos que ele não é o mesmo, é em consequência de sua comunidade com "o outro", comunidade esta que o separa do "mesmo" e o torna nãomesmo, e sim outro; de sorte que, neste caso, temos o direito de chamá-lo "não-o-mesmo" (PLATÃo, 1979, 256a-b, grifo nosso).

Assim, ser o mesmo e não ser o mesmo implica que ser e não-ser são faces da mesma moeda: partilham da mesma substância, o Ser. Ou seja, o que é o Ser? É ser e é não-ser:

ESTRANGEIRO - Sabes, a este respeito, que nosso desafio a Parmênides, nos levou bem além dos limites por ele interditados?

TETETO - Para onde?

ESTRANGEIRO - Levamos nossas pesquisas muito além, estendendo-as a um campo bem mais vasto que aquele que ele nos permitia explorar, e, contra ele, estabelecemos nossas demonstrações.

TEETETO - Como? 
ESTRANGEIRO - Se me recordo, ele disse: "Jamais obrigarás os nãoseres a ser; antes, afasta teu pensamento desse caminho" (PLATÃO, 1979, 258 c-d).

Para ficar mais bem entendido, é necessário elencar os gêneros e demonstrar, pelo viés do Estrangeiro, "que o não-ser é um gênero determinado entre os demais, e que se distribui por toda série de gêneros" (1979, 260b). Vejamos, pois:

1. Sobre o gênero movimento, como já demonstrado acima, ele "é" em relação a si próprio. Porém, "não-é" em relação ao repouso;

2. Sobre o gênero repouso, do mesmo modo, ele "é" em relação a si próprio. Porém, "não-é" em relação ao movimento;

3. Sobre o gênero ser, "é" igual a si mesmo. Porém, dado que os gêneros antagônicos, de movimento e de repouso, dele participam, guarda em si a diferença, ou seja, o "não-ser" idêntico a si mesmo;

4. Sobre o gênero mesmo, "é" sempre a identidade imóvel e absoluta. Contudo, ao ser predicado do movimento e do repouso (quando se diz do movimento e do repouso como sendo os mesmos em relação a si próprios), passa a ser o "não-ser", identidade imóvel e absoluta.

5. Sobre o gênero outro, "é" enquanto identidade de ser outro. Porém, como nunca é si-mesmo (em substância), é, então, um "não-ser" em si. Tal gênero participa de todos os demais, pois que cada um deles, "com efeito, é outro além do resto" (1979, 255e).

Dada a ordem dos gêneros e sua imbricação com o não-ser, o que incorre necessariamente em seu ser, o Estrangeiro trata do discurso e da opinião falsos, enquanto não-seres: "O fato de serem não-seres o que se enuncia ou se representa, eis o que constitui a falsidade, quer no pensamento, quer no discurso" $(1979,260 c)$.

A questão é que o Estrangeiro revela dois tipos de não-seres: o tipo que participa do ser - e que, portanto, é dialético e verdadeiro -; e o que não participa do ser - e que, portanto, por sua ilogicidade intrínseca, conduz ao engano, ao erro. Desse segundo tipo de "não-ser" se apossam, em seus atos discursivos e/ou opinativos (ambos simulacros), os sofistas. Mas em que sentido o "discurso" e a "opinião"?

Para o Estrangeiro, discurso é toda união de verbos a nomes. Isolados, verbos e nomes não formam nenhum discurso. Por exemplo, dizer "anda, corre, dorme, e todos os demais verbos que significam ação; mesmo dizendo-os todos, um após outro, nem por isso formam um discurso" (1979, 262b). Do mesmo modo, dizer "leão, cervo, cavalo, e todos os demais nomes que denominam sujeitos executando ações, há, ainda, uma série da qual jamais resultou discurso algum" (1979, 262c). Ou seja, tomados isoladamente, verbos e nomes formam um não-ser. Somente sua combinação adequada é que faz nascer o discurso, mesmo que em versão breve: "ESTRANGEIRO - Ao dizeres: o homem aprende não reconheces ali o discurso, o mais simples e o primeiro? TEETETO - Para mim, sim." (1979, 262d).

Tem-se, em primeiro lugar, que o mútuo acordo dos sinais vocais possibilita o ser do discurso. Em segundo, que esse ser só é mantido se e somente se o discurso tratar de coisas (seres), pois, do contrário, discorrer sobre o nada (o não-ser sofístico) deslegitima imediatamente o ser. Acontece que tratar sobre o nada pressupõe, para o Estrangeiro, igualmente tratar sobre o falso. Por exemplo: dizer que Teeteto está sentado é algo perfeitamente admissível e, portanto, fundamenta o ser do discurso. Por outro lado, dizer que Teeteto está voando é falso e, portanto, presume o nãoser do discurso.

À guisa de concluir é que o Estrangeiro discorre sobre o que é pensamento e o que é discurso: afirma serem a mesma coisa, sendo que o "pensamento" é um discurso da alma em um diálogo consigo mesma. Em seguida, diz que a conclusão do diálogo que a alma trava consigo deve ser chamada de "opinião"; por sua vez, que a opinião, quando associada 
a sensações, deve receber o nome de "imaginação". Assim, pensamento, opinião e imaginação, como partes constituintes do discurso, são sempre pelo homem erigidas. Tem-se, pois, que o homem é instrumento do discurso.

Quando, porém, tal instrumento produz discurso falsos (não-seres), baseados em sensações que não endossam as ciências, eis que se pode chamá-lo de homem do simulacro, um ser humano nonsense, que pratica a arte da mímica sobre o não fundado (no ser). São estes, para o Estrangeiro, os sofistas.

\section{Ducrot e o Sofista}

Posto o fundamental sobre o diálogo Sofista, ainda que de forma sucinta, cabe agora analisar as reflexões teóricas sobre o mesmo, as quais Ducrot erigiu no Prefácio ao $O$ Intervalo Semântico, de Vogt. Nesse prefácio, como atesta o próprio Ducrot, objetiva-se colocar Vogt "sob a proteção de Platão" (2009, p. 10), no sentido de que Platão, "abrigando-se, por sua vez, atrás do misterioso personagem do 'Estrangeiro', apresenta, em $O$ Sofista, uma teoria da alteridade" (2009, p. 10).

Ora, em que sentido "uma teoria da alteridade" apresentada pelo Estrangeiro? No sentido - enfatiza-se a lição de Platão no Sofista - de que o ser só se mostra em comparação a outro. Trata-se do caminho do paradoxo do ser, que prediz que todo ser é idêntico a si mesmo, portanto não pode participar de outro ser. Contudo, o que substancialmente é idêntico a si mesmo só pode ser reconhecido enquanto tal se posto em comparação a o outro ser que lhe é diferente. Ou seja, qualquer ser só é em função de sua distinção ao que ele não-é.

Por essa perspectiva, tomando-se por objeto a língua, e de acordo com o viés saussuriano, tem-se que o conceito é sempre sinônimo de significado (o qual só "é" enquanto contraparte inteligível), e a forma de expressão do significado é o significante (a parte sensível do significado). No viés platônico, pode-se dizer que o significado saussuriano está para o "plano suprassensível" (das ideias) e que seu significante, para o "plano das formas sensíveis", as quais nada mais são que cópias das primeiras e que, quando fundamentadas nas ciências - como alerta o Estrangeiro -, expressam acertadamente o ser e de muitos modos. Quando fundamentadas nas meras opiniões (o reino da doxa), expressam não o ser, propriamente dito, mas os simulacros do ser (a sofística do "não-ser", enquanto realidade nonsense).

Voltando a Saussure e ao conceito de alteridade, o significante é dito a imagem acústica do significado, "não é o som material, coisa puramente física, mas a impressão psíquica desse som" (1969, p. 80). Com efeito, temse que o signo linguístico é "uma entidade psíquica de duas faces" (1969, p. 80). A alteridade dá-se ainda num segundo plano, o ser de cada vocábulo (seu valor linguístico) só "é" quando em oposição a outros vocábulos. Nesse sentido, Ducrot observa que

(...) o Cours de linguistique générale, no capítulo sobre o Valor, não faz senão aplicar às palavras da língua o que Platão disse sobre as Ideias. A oposição, para Saussure, é constitutiva do signo da mesma forma que a alteridade é, para Platão, constitutiva das ideias. 0 valor de uma palavra ou seja, sua realidade linguística - é o que opõe às outras. Indo mais longe, é a de se opor às outras (DUCROT, 2009, p. 10-11).

Ora, de certa forma, a demonstração de Saussure revela que a realidade linguística só "é" pelo viés do gênero outro elencado pelo Estrangeiro. Ou seja, a realidade linguística não se mostra em si mesma sem que seu outro não protagonize, em concomitância, o seu sentido. Dessa forma, na elucidação do próprio "ser", o valor de um signo é constitutivo tão somente na alteridade.

Em outras palavras, 
Para reencontrar na sua essência o platonismo saussuriano, é preciso reconhecer na linguagem uma função mais fundamental. Uma função que se satisfaça com a pura alteridade, ou mesmo que a implique. É justamente o que fazem, há alguns anos, certos linguistas cuja reflexão alimentou-se das pesquisas de Emile Benveniste. Para eles, e para Vogt especialmente, a língua é, antes de mais nada, o lugar da intersubjetividade, o lugar onde os indivíduos se confrontam, o lugar onde encontro outrem. Ora, outrem, ou não é nada, ou é este outro constitutivo de que fala Platão, este outro que me constitui a mim mesmo, porque é somente através dele que posso me ver e é através do seu reconhecimento que posso me conhecer (DUCROT, 2009, p. 11).

Sim, é dito que esse outro de que fala Platão é constitutivo pela lógica dedutiva do Estrangeiro, cuja inferência é a de que a identidade das coisas (mesmas) dá-se a partir do processo comparativo a outras coisas que lhes são distintas (outro). Por exemplo, a definição "homem, animal racional" é tomada ao domínio do inteligível, enquanto significando homem inteligente. Todavia, seu sentido essencial não existe sem o contraponto à sua definição predicativa imediatamente oposta, "animal não racional/não inteligente". Isso implica, entretanto, que os termos "animal" e "racional", para que suas identidades possam vir à luz, devam também ser contrapostos isoladamente a seus antônimos. Contudo, ao se fazer isso, se recai sobre um problema: que ideia é primordialmente fundante de "animal" ou de "racional" ou de seus antônimos? Embora esses últimos sejam causas necessárias para que haja a devida compreensão de "animal" e "racional", não são causas suficientes. Haverá, pois, uma ideia ${ }^{6}$ primordial que fundará todas as demais ideias, possibilitando o máximo de compreensão dos termos? Para que não

${ }^{6} 0$ termo Ideia, empregado por Platão (do grego éidos), “(...) a tradução exata do termo seria 'forma'. (...) Com efeito, nós, modernos, com 'ideia' entendemos um conceito, um pensamento, uma representação mental, algo enfim que nos leva ao plano psicológico e noológico; Platão, ao contrário, com 'Ideia' entendia, em certo sentido, algo que constitui o objeto específico do pensamento, ou seja, aquilo a que o pensamento se dirige de modo puro, sem o que o pensamento não seria pensamento. Em resumo, a Ideia platônica não é realmente puro ente de razão, mas é um ser, mais ainda, aquele ser que existe de forma absoluta, o verdadeiro ser". (REALE; ANTISERI, 2003, p. 139) se incorra no absurdo de elencar ideias ad infinitum, e em se propondo demonstrar as identidades do ser de todos os termos, Platão elencou uma hierarquia de ideias - não no Sofista, mas em A República (Livro VII) - na qual o Bem aparece como a ideia primordial, fundante de todas as demais. Assim, as ideias que expressam iniquidades, por exemplo, são aquelas corrompidas pelo mau uso da razão em abstrair as nuances do Bem.

Para Platão, o Bem pode ser abstraído tão somente pelo viés intelectivo, o que, para ele, significa primordialmente o emprego da relação simbiótica entre razão e alma, e jamais entre razão e sensações.

Para que a razão, pelo mergulho na alma, possa abstrair com toda a propriedade o Bem universal, o processo dialético deve protagonizar a busca, segundo Platão, para quem a fundamentação de todo o logos (razão) ocorre tão somente por esse processo dialógico.

Ora, o aspecto supracitado do significado saussuriano, cujo gênero outro é imprescindível para a sua determinação, coloca-o fundamentalmente na ordem do opositivo, pois jamais o significado (das palavras, dos enunciados, dos discursos) pode ocorrer fora do emprego dialógico (DUCROT, 2009) - o que subscreve Platão.

Ducrot, por essa mesma via, irá fundamentar o ato linguístico afirmando que "o enunciado se definirá então pelas possibilidades de resposta que se abre e por aquelas que se fecha" (2009, p. 11-12), justamente no jogo dialógico, em que o locutor constrói seus argumentos e por esses, ao mesmo tempo, molda as possibilidades de respostas de seu alocutário. Assim, e à la Estrangeiro de Eléia, Ducrot torna o próprio enunciado um não-ser em si, dado que sua dimensão de sentido só se completa em alusão a outros seres, ou seja, "a outros enunciados - aqueles pelos quais ele quer ser continuado, este futuro discursivo que projeta diante de si esta sombra de si mesmo que é a sua única realidade" (2009, p. 12). 


\section{Ducrot, sobre o trabalho de Vogt}

Entretanto, após chamar Vogt de "positivo", Ducrot não insiste nessa postura do dialogismo opositivo platônico, embora ao ter-se utilizado dela tenha ampliado o próprio horizonte de sentido do que vem a ser esse positivo na "decência linguística atual" (2009, p. 12) - o que endossa, outra vez, Platão: o ser se mostra na medida do que mostra o não-ser.

Sobre o intervalo semântico de que fala Vogt - o foco do Prefácio -, Ducrot afirma que se trata de algo que muito se assemelha ao gênero outro de Platão, justamente porque as etapas da demonstração de Vogt fazem emergir primordialmente sempre a noção de outro.

Na primeira etapa da demonstração, aparece o elemento comparativo como produtor de sentido na língua: "tudo, na língua, é comparação ou, pelo menos, muita coisa - muito mais do que se pensa habitualmente" (2009, p. 12). Ducrot cita, como exemplo, os elementos conjuntivos em um discurso (mas, também, mesmo, ainda, já...), cujo papel é o de direcionar as conclusões dos argumentos e, com isso, de direcionar o interlocutor a um conjunto específico de respostas. Porém, antes disso, tais partículas de conjunção fazem com que duas ou mais proposições se juntem em uma argumentação - eis sua relação ao gênero outro, pois que juntam uma proposição a outra e "terminam sempre por confrontar dois dados, por colocá-los na balança" (2009, p. 12). Mas o uso da conjunção é já “colocar-se fora das coisas que se dizem, no seu intervalo" (2009, p. 12).

O que Ducrot e Vogt querem com isso dizer é que, quando se emprega, num determinando enunciado, a partícula mas, é porque esse mas faz advir uma nova proposição, que irá ampliar o sentido da anterior. É justamente o tempo desse mas que está indicando o intervalo semântico no enunciado e seu emprego implica um colocar-se fora da proposição precedente, pois já não se está mais a dizê-la isoladamente; com o mas o que se quer é dizer algo mais. Eis um exemplo: amanhã irei à sua casa estudar, mas se chover não poderei ir. Ora, a proposição amanhã irei à sua casa estudar indica um conteúdo $x$. A utilização domas se coloca fora desse conteúdo e o quebra, pois confronta-o com a possibilidade de não-x. Outro exemplo: amanhã irei à sua casa estudar, mas se chover você terá que vir de carro me buscar. Nesse exemplo, a proposição primeira continua a guardar o mesmo conteúdo $x$ e a utilização domas, ainda que posicione o enunciador fora da primeira proposição, o faz confrontando-a de modo mais conciliativo em relação a $x$, mas sem excluir a possibilidade de não- $x$ (caso chova e não receba a carona combinada, então não há garantia de $x$ ).

Trata-se, pois, de um "movimento de realização que conduz de uma à outra, que conduz a esta segunda etapa de que vamos falar agora" (2009, p. 13). A segunda etapa da demonstração de Vogt pressupõe a comparação entre uma coisa $A$ e outra $B$, no sentido de que uma não será aquilo que é senão por referência ao que é a outra. Por exemplo, se Pedro quer comprar um carro novo e a concessionária, após saber de Pedro o perfil de carro que mais lhe agrada, lhe oferece dois carros (A e B), para que se decida por um ou por outro. Pedro, então, pensará que a escolha será simples: basta decidir-se pelo carro que temo melhor preço. Acerca dessa comparação, Ducrot observa:

O conhecimento da relação parece, portanto, sem nenhuma dúvida possível, o objetivo da comparação. Ora, acontece que, para atingir este objetivo, devo começar, habitualmente, por informar-me sobre cada um dos objetos, tomados individualmente. Assim, para determinar qual é o menos caro, sou obrigado a procurar, antes de mais nada, qual é o preço de um e de outro - o conhecimento dos termos aparecendo aqui como um simples meio de conhecimento de suas relações (DUCROT, 2009, p. 13).

Contudo, a decisão de Pedro será mais precisa se ele comparar não só os preços, mas também as características de cada automóvel, pois se A oferece 
mais conforto, durabilidade e potência que B, então, mesmo que A tenha o maior preço, pode ser que seja "o mais barato", dadas as suas características superiores em relação a B. Sendo assim,

Não há nada mais claro, mais simples, mais lógico - aparentemente - que essa descrição da comparação: considero sucessivamente as duas coisas comparadas, e concluo, em seguida, que relação elas têm entre si. Poderia ser diferente? Para saber se A é diferente de B, e em que é diferente, é preciso começar por saber o que é A e o que é B (DUCROT, 2009, p. 13).

Para Vogt, segundo Ducrot, o problema é que as conjunções que possibilitam as comparações não se situam "entre" os objetos comparados (A e B) - o que faria jus à etimologia do termo "intervalo" - mas se entranham nos objetos (ou proposições em que os objetos são predicados), moldando suas realidades. Por exemplo, quando o vendedor da concessionária diz que $B$ é potente, mas $A$ é ainda mais potente, o uso desse elemento linguístico mas, que configura o intervalo semântico entre $\mathrm{A}$ e $\mathrm{B}$, em verdade não se posiciona "entre" as proposições; se posiciona "nas" proposições, no sentido de que dão as cartas ao conteúdo de cada uma. Ou seja, o mas "as torna aquilo que elas são" (2009, p. 15).

Ducrot revela, com isso, um problema: se se quer bem conhecer as propriedades de A, ao modo do Estrangeiro platônico, é necessário contrastá-las a outras propriedades distintas, como as de B. Porém, ao se fazer isso, se cai sobre a comparação, que exclui - como visto no parágrafo anterior - o real conteúdo das propriedades tanto de A quanto de B. Mais uma vez, o que A e B "são" só é possível saber na comparação entre ambos; mas a comparação entre ambos não traz à luz nem o ser de A nem o de B, senão o seus "não-seres". Que fazer?

Para encontrar uma saída, é preciso admitir (...) que o ato de fala fundamental, aquele, em todo caso, que se exprime através da maioria das frases comparativas, é o ato de argumentar, de obrigar outrem, através das palavras que pronunciamos, a dirigir-se para tal ou qual tipo de conclusão. A significação do enunciado residiria então menos no que ele diz do que na orientação que dá à sequência do discurso. Descrever um enunciado seria, antes de qualquer outra coisa, descrever aonde ele conduz (DUCROT, 2009 , p. 16)

Eis a terceira etapa da demonstração do intervalo semântico: segundo Ducrot, o que está implicado num enunciado não é a definição em si dos termos nele empregados, mas ao que conduz sua conclusão. Por exemplo, se Pedro decide não comprar o automóvel A (ainda que seja o mais potente, o mais confortável, o mais durável), mas, sim, o B, por lhe agradar mais a cor e o preço, o vendedor da concessionária, decidido, em sua lógica, por vender o mais caro (o automóvel A), argumenta que a cor do automóvel A é tão bonita quanto a de B. Ora, o que pretende com isso? “(...) dirigir seu interlocutor em direção a um certo gênero de conclusão" (2009, p. 16). Não se trata, pois, de descrever nem a $\mathrm{A}$ nem a $\mathrm{B}$, em suas propriedades intrínsecas. O que está em jogo é a argumentação que quer orientar a resposta do interlocutor. Para Ducrot, essa etapa revela que o sentido do enunciado não é a definição das propriedades de seus termos. 0 sentido do enunciado é a argumentação orientada ao outro, ou seja, o sentido se completa no outro (no alocutário).

Enfim, a "determinação tirada do enunciado comparativo é de ordem argumentativa" (2009, p. 17). Parafraseando Ducrot, o intervalo semântico faz emergir um conhecimento argumentativo que diz respeito não ao que são as propriedades de $\mathrm{A}$ ou de $\mathrm{B}$, "mas ao que disso se deve concluir, às consequências que disso se devem tirar" (2009, p. 17).

A quarta etapa da demonstração é sobre um último "problema que levanta o trabalho de Vogt, problema que Vogt apresenta como uma preparação" (2009, p. 18) - tanto que é apresentado logo no primeiro capítulo do seu $O$ Intervalo Semântico -, mas que Ducrot considera antes 
como sendo um prolongamento. Trata-se de uma questão estrutural metodológica do intervalo:

Onde situar, com relação ao intervalo metodológico, o que chamamos o intervalo semântico, isto é, estas relações do locutor ao destinatário que constituem o próprio sentido de nossos enunciados, e que lhes dão uma organização fundamentalmente comparativa? A resposta de Vogt é que estes dois intervalos, na realidade, não constituem senão um só (DUCROT, 2009, p. 18).

Ou seja, em que ordem guardar as proporções teóricas do intervalo na teoria linguística geral? Será em definir suas estruturas internas (o objeto formal da linguística) separando-as de seu dado empírico? Entre estrutura e dado, eis um intervalo metodológico. $O$ que Vogt sugere que é que se deve "deixar o domínio da estrutura, e colocar-se entre a estrutura e o dado" (2009, p. 18), ou seja, lá onde o intervalo metodológico (da linguística) encontra o mesmo "entre" do intervalo semântico (da língua). Assim, "não apenas o locutor, que fala na língua, mas também o linguista, que fala sobre a língua, não poderiam formular uma fala" (2009, p. 19) que não incorresse no mesmo lugar comum.

Ducrot tem dúvidas quanto a essa postura. Ele conjectura que "talvez a tarefa do linguista seja justamente a de integrar nas estruturas que ele constrói uma parte cada vez maior desse intervalo semântico" (2009, p. 19), na teorização das relações entre enunciador e enunciatário.

\section{Considerações finais}

O que se pode depreender das reflexões trazidas por Ducrot, em seu Prefácio, é que o intervalo semântico, de que fala Vogt, está implicado, especificamente, no resultado de processos argumentativos, cujo objetivo é convencer os alocutários. Nesse sentido, cabe o risco de uma pergunta inquietante: as quatro etapas do intervalo semântico de que fala Vogt, segundo Ducrot, não endossam, em verdade, um modus operandi de argumentação que se assemelha ao do sofista? Pois, se este tem por objetivo conduzir seus interlocutores a certos tipos de conclusão e não a outros, ainda que com sua oratória erística, seria algo de natureza análoga ao que propõe o "conhecimento argumentativo", da explanação de Ducrot.

Dito de outro modo, se o intervalo semântico faz emergir a maior importância não ao que diz o enunciado, mas ao que ele conduz, então esse mesmo intervalo corrobora o relativismo enunciativo dos sofistas, o qual não está preocupado com o ser dos termos, mas com o resultado que gera a boa reunião dos termos, ou seja, está preocupado com o fim último do processo argumentativo (convencer o alocutário) e jamais com o fim do universalismo epistemológico de Platão, que exige, pelo processo dialético, que se ponha às claras o ser de cada termo, extraído do plano suprassensível das ideias perfeitas e universais.

Sendo assim, se se tratar de um problema pertinente, então Ducrot, no tocante a tal questão (e tão somente), cumpre sua missão, ao estilo do Estrangeiro, qual seja, de revelar o ser (da natureza discursiva da erística sofística) pela via do não-ser (do ser outra coisa que não o totalmente oposto à sofística).

De qualquer forma, deve-se tomar, ao menos, o que a questão pretende conduzir, enquanto escopo argumentativo, a saber, a reflexão cada vez mais profunda e abrangente sobre o ser e o não-ser do Prefácio.

\section{Referências}

ABBAGNANO, Nicola. Dicionário de Filosofia. Tradução de Alfredo Bosi e Ivone Castilho Benedetti. São Paulo: Martins Fontes, 2007.

BURNET, John. A aurora da filosofia grega. Trad. Vera Ribeiro. Rio de Janeiro: Editora PUC-Rio, 2006. 
DUCROT, Oswald. Prefácio. In: VOGT, Carlos. O Intervalo Semântico (contribuição para uma Teoria Semântica Argumentativa). São Paulo: Ateliê Editorial/Campinas: Editora da Unicamp, 2009. p. 9-19.

PLATÃo. Diálogos - Sofista. Trad. Jorge Paleikat e João Cruz Costa. São Paulo: Abril Cultural, 1979. (Coleção Os pensadores).

REALE, Giovanni; ANTISERI, Dario. História da filosofia: filosofia pagã antiga. Trad. Ivo Storniolo. Paulo: Paulus, 2003

SAUSSURE, Ferdinand de. Curso de linguística geral. Trad. Antônio Chelini, José Paulo Paes e Izidoro Blikstein. São Paulo: Cultrix, 1969.

Recebido: 20/07/2017

Aceito: $15 / 11 / 2017$ 